\title{
ANALISIS KEBIJAKAN PENDIDIKAN DALAM PERSPEKTIF MADRASAH
}

\author{
Oleh: \\ Wahyu Iskandar \\ Universitas Islam Negeri Sunan Kalijaga \\ Yogyakarta \\ Wiskandar921@gmail.com
}

\begin{abstract}
Abstrak
Madrasah memiliki peran strategis dalam pembangunan bangsa. Saat ini pendidikan madrasah masih dianggap pendidikan "kelas dua". Hal ini terjadi karena penyelenggaraan madrasah masih menghadapi sejumlah masalah besar mulai seperti persoalan pengelolaan dan rendahnya mutu pendidikan madrasah. Tulisan ini dimaksudkan untuk memberi gambaran tentang kiprah madrasah dalam sistem pendidikan di Indonesia, permasalahan madrasah, peluang, dan tantangan madrasah. Madrasah telah menjadi bagian dari sistem pendidikan nasional. Metode yang digunakan dalam kajian ini adalah studi kepustakaan dengan mengumpulkan data sekunder dari berbagai sumber buku dan jurnal, kemudian melakukan analisis deskriptif data yang dipaparkan secara detil. Berbagai persoalan dihadapi madrasah antara lain pengelolaan pendidikan, kesenjangan antara negeri dan swasta, mutu madrasah, sampai kepada peluang dan tantangan tersendiri bagi madrasah di Indonesia pada saat ini.
\end{abstract}

Kata kunci : Madrasah, Pendidikan, Peluang Madrasah

\begin{abstract}
Madrasah has a strategic role in nation building. Currently the education of madrasa education is still considered "second class". This occurs because of the implementation of the madrasa still faces a number of major issues such as the management problems start and the low quality of madrasah education. This paper is intended to give an overview of the progress madrasah education system in Indonesia, madrasas issues, opportunities and challenges of the madrasa. Madrasah has become part
\end{abstract}

Al-Madrasah: Jurnal Ilmiah Pendidikan Madrasah Ibtidaiyah

Vol. 4, No. 1, Juli-Desember 2019 
of the national education system. The method used in this study is a literature study by collecting secondary data from various sources of books and journals, and then perform a descriptive analysis of the data presented in detail. Various problems encountered include management madrassa education, the gap between public and private, the quality of madrasah, to the opportunities and challenges for madrasah in Indonesia at this time.

Keywords: Madrasah, Education, Opportunity Madrasah

\section{A. Pendahuluan}

Pendidikan merupakan hal yang sangat penting untuk dibicarakan sebab biasanya kecerdasan manusia dilihat dari seberapa tinggi seseorang tersebut mengenyam pendidikan. Dengan adanya pendidikan, manusia juga dapat mencapai kebutuhan hidupnya dengan berbagai cara. ${ }^{1}$ Dalam hal ini pemerintah juga tidak bermain-main dalam menggalakkan pendidikan, terbukti dengan adanya salah satu peraturan yang mengatur pendidikan yang tertuang dalam UUD 1945 pasal 31 ayat 1,2 an $3 .^{2}$

Berkaitan dengan hal ini proses pendidikan juga ada tiga lingkungan penting yang berpengaruh terhadap keluarga, sekolah dan masyarakat. ${ }^{3}$ Bangsa Indonesia juga sudah terbiasa dengan pernyataan bahwa pendidikan merupakan tanggung jawab bersama antara keluarga,

\footnotetext{
${ }^{1}$ Rifka Anna Miratul Faidah, Analisis kebijakan Pendidikan Dalam Perspektif Lingkungan Madrasah : Yogyakarta, K-Media, 2018, h.209

${ }^{2}$ UUD 1945 pasal 31 ayat 1 tiap tiap warga Negara berhak mendapat pengajaran. Ayat 2 pemerintah mengusahakan dan menyelenggarakan saru sistem pengajaran nasional yang telah di atur oleh payung hukum. Ayat 3 pemerintah mengusahakan dala menyelenggarakan satu sistem pendidika Nasional yang meningkatka keimanan dan ketakwaan serta akhlak mulia dalam rangka mencerdaskan kehidupan bangsa yang diatur dengan undang undang. Lihat dalam Hak dan kewajiban warga Negara dalam UUD 1945 Pasal 31

${ }^{3}$ Dalam konteks yang lebih luas, setiap individu adalah pendidik, dimana peran sentral orang tua, masyarakat dan pendidik menjadi faktor penting dalam membentuk karakter siswa, setiap indivi juga memiliki tanggung jawab pendidik. Setiap pendidik memiliki tugas kependidikan dan hal itu hendaknya bisa dijalankan dengan baik karena setip orang memiliki tanggungjawab untuk membentuk generasi penerus tentu dengan adanya kombinasi mendidk dari peran orangtua, masyarakat dan pendidik. Lihat dalam Moh Roqib, ilmu pendidikan islam, (Yogyakarta, PT Lkis, 2009) h. 37
}

\section{Al-Madrasah: Jurnal Ilmiah Pendidikan Madrasah Ibtidaiyah}

Vol. 4, No. 1, Juli-Desember 2019 
masyarakat, dan pemerintah, seperti yang dinyatakan pada penjelasan pasal 25, ayat (1) butir 1, UU sisdiknas No 2 Tahun $1989,{ }^{4}$ sayangnya pemahaman dan kesadaran akan tiga lingkungan pendidikan, dan tanggungjawab ketiganya tidak dimaknai secara tepat dengan tataran secara operasional menguntungkan peserta didik.

Sebelum berbicara konsep pendidikan dalam perspektif madrasah tentu harus mengetahui nilai kultural religius yang dicita-citakan masyarakat dan pemerintah terkait pendidikan di madrasah, yakni dengan harapan madrasah mampu memproduksi lulusan yang berkualitas dalam pengetahuan umum dan agama sesuai dengan standar pendidikan Nasional. Dalam kaitan ini Madrasah tersebut memiliki payung hukum sesuai dengan amanat Undang-Undang Nomor 20 Tahun 2003 tentang Sistem Pendidikan Nasional dan Peraturan Pemerintah Nomor 55 Tahun 2007 tentang Pendidikan Agama dan Pendidikan Keagamaan dalam bentuk Raudhatul Athfal (RA), Madrasah, dan Perguruan Tinggi Agama, serta Pendidikan Agama dan Pendidikan Keagamaan.

Senada dengan hal diatas Faridah alawiyah menuliskan dalam jurnal Aspirasi :

Kiprah madrasah dalam membangun karakter bangsa dengan penanaman nilai-nilai agama sebagai bagian dalam penyelenggaraan pendidikan disamping pemberian ilmu pengetahuan umum perlu menjadi perhatian. Karena penyeleggaraan pendidikan madrasah telah mendorong pendidikan di Indonesia semakin besar. Membantu pencapaian wajib belajar, serta meningkatkan angka partisipasi sekolah di Indonesia. Sebagai bagian integral dalam Sistem Pendidikan Nasional (Sisdiknas). Saat ini jumlah madrasah di Indonesia telah tersebar ke seluruh pelosok negeri. Menurut data dari Kemenag 2011 jumlah madrasah di Indonesia sudah mencapai lebih dari 43.640 buah. Angka

\footnotetext{
${ }^{4}$ Setiap peserta didik berkewajiban untuk: a, ikut menanggung biaya penyelenggaraan pendidikan, kecuali bagi peserta didik yang dibebaskan dari kewajiban tersebut sesuai dengan peraturan yang berlaku. b, mematuhi semua peraturan yang berlaku. c..menghormati tenaga kependidikan yang bersangkutan. d, ikut memelihara sarana dan prasarana serta kebersihan ketertiban dan keamanan satuan pendidikan yang bersangkutan. lihat dalam pasal 25, ayat (1) butir 1, UU sisdiknas No 2 Tahun 1989
}

Al-Madrasah: Jurnal Ilmiah Pendidikan Madrasah Ibtidaiyah Vol. 4, No. 1, Juli-Desember 2019 
ini memberikan kontribusi besar untuk meningkatkan angka partisipasi sekolah dalam pencapaian wajib belajar. Disamping itu salah satu poin penting dalam RPJMN 2010-2014 Kementerian Agama dalam program dan strategi pelaksanaan kegiatan di tahun 2010-2014 yaitu peningkatan kualitas raudhatul athfal, madrasah, perguruan tinggi agama, pendidikan agama, dan pendidikan keagamaan. ${ }^{5}$

Hal ini akan memacu terselenggaranya pendidikan menjadi lebih baik. $^{6}$ Namun demikian, dalam pelaksanaannya pendidikan madrasah seringkali masih dipandang sebelah mata. Madrasah dianggap sebagai pendidikan 'kelas dua' setelah pendidikan formal yang diselenggarakan Kemendikbud. ${ }^{7}$ Pendidikan yang diselenggarakan di madrasah dinilai kurang berkualitas, lulusannya dianggap belum mampu bersaing dengan lulusan satuan pendidikan yang sederajat, dan tata kelola lembaganya juga tidak berkualitas. Sehingga, sebagian masyarakat masih menjadikan madrasah sebagai pilihan terakhir untuk

${ }^{5}$ Faridah Alawiyah, Pendidikan Madrasah di Indonesia, (Jurnal Aspirasi Vol. 5 No. 1, Juni 2014)

${ }^{6}$ Menurut Dede Rosyada sekolah akan mencapai peforma terbaik jika dipimpin oleh kepala sekolah yang kuat dan visioner, konsisten, demokratis dan menyampaikan gagasan gagasan besar serta mengambil keputusan yang strategis. Kemudian dia mampu mendorong motivasi guru, staf dan siswa siswanya untuk terus berprestasi terbaik, selain itu sekolah juga menerapkan perhatian pada pembelajaran siswa dan guru bersama siswa mengembangka kerjasama proses pembelajaran secara efektif dalam prinsip collaborative learning, guru mengajar dengan konsisten mendorong siswanya dalam belajar secaraoptimal. Lihat dalam Dede Rosyada, Paradigma Pendidikan Demokratis, (Jakarta, Prenada Media Group, 2003), h.221

${ }^{7}$ Menurut A. Malik Fajar dalam jurnal yang ditulis oleh Ranti Syafiah dalam hal ini berkomentar bahwa pemaknaan madrasah di Indonesia lebih dikenal dengan sekolah agama. Secara tidak langsung hal tersebut menyempitkan arti dari madrasah itu sendiri, membuat seolah madrasah memiliki makna yang berbeda dan lebih sempit bila dibandingkan dengan sekolah dasar. Stigma demikian agaknya masih terus berkembang ditengah masyarakat. Masyarakat masih saja memandang madrasah sebagai lembaga pendidikan yang tidak setara dengan sekolah dasar. Suka atau tidak suka ilmu pengetahuan modern lahir dari rahim filsafat Yunani (6 SM) yang dibesarkan oleh gerakan Renaissance (16 M), Reformasi (17 M), dan Pencerahan (18 M) di Eropa Barat yang dengan lugas/tegas menyatakan diri tidak bersumber dari ajaran keesaan Tuhan. lihat dalam Ranti Syafi'ah, Upaya Pengembangan Madrasah Ibtidaiyah Ma'arif Bego dari Tahun Ajaran 2011/2012 - 2014/2015, ( Jurnal Pendidikan Madrasah, Volume 2, Nomor 2, November 2017), h. 237

Al-Madrasah: Jurnal Ilmiah Pendidikan Madrasah Ibtidaiyah Vol. 4, No. 1, Juli-Desember 2019 
menuntut ilmu.

Bila melihat dari komposisi materi yang diberikan kepada siswa 40\% merupakan materi keagamaan yang ditanamkan pada setiap sisi. Padahal, ditengah krisis moral yang terjadi saat ini, dan ketika pendidikan umum sudah tidak dapat lagi memenuhi tuntutan perbaikan karakter dan moral bangsa, maka demikian kiprah madrasah tidak dapat dipandang sebelah mata karena madrasah memiliki peran penting dalam pendidikan nasional secara bersama membangun pendidikan ke arah yang lebih baik $^{8}$ demi terwujudnya bangsa yang cerdas dan berakhlak mulia.

\section{B. Metodologi Penelitian}

Tulisan ini bertujuan membahas mengenai analisis kebijakan pendidikan dalam perspektif madrasah di Indonesia termasuk didalamnya kiprah dan kedudukan madrasah dalam sistem pendidikan nasional, persoalan, peluang dan tantangan yang dihadapi madrasah di Indonesia. Kajian ini menggunakan metode studi kepustakaan dengan mengumpulkan data sekunder dari berbagai sumber seperti buku dan jurnal. Kemudian melakukan analisis deskriptif data yang dipaparkan secara detil.

\section{Hasil dan Pembahasan}

\section{Sejarah Madrasah di Indonesia}

Eksistensi madrasah juga pembaruannya di Indonesia baru dijumpai pada awal abad 20 baik aspek fisik maupun nonfisik ${ }^{9}$ melalui banyak kejadian dan historiografi. Dimana beberapa penulis sejarah

${ }^{8}$ Madrasah merupakan sekolah umum plus karena di dalam madrasah diajark mata pelajaran umum sebagaimana yang ada di seklah sekolah umum, dan juga diajarkan mata pelajaran agama yang cukp memadai. Jika dikelola dengan baik dan berkualitas maka madrasah akan menjadi orientasi lembaga pendidikan di Indonesia. Lihat dalam Moh Roqib, ilmu pendidikan islam, (Yogyakarta, PT Lkis, 2009) hx. 138

${ }^{9}$ Abudin Nata, Sejarah Pendidika Islam, (Jakarta, Kencana, 2016), h. 334 
pendidikan Islam di Indonesia menyebutkan ada dua peristiwa penting yang melatarbelakangi munculnya madrasah di Indonesia, yaitu dengan adanya kolonialisme Belanda dengan misi misinya ${ }^{10}$ dan gerakan pembaharuan Islam.

Pada kaitannya Muhammad qosim berkomentar dalam jurnal tadris yaitu :

Selama menjajah Indonesia, pemerintah Hindia Belanda memperlihatkan sikap preventif dan diskriminatif terhadap umat Islam diindonesia. Misalnya, pemerintah membuat regulasi sebagaimana tertuang dalam pasal 179 (2) Konstitusi Hindia Belanda (Indische Staatsregeling) yang melarang pelajaran yang berbau spiritualis agamis keislaman tidak diajarkan di sekolah umum milik pemerintah dengan alasan pemerintah bersikap otonom. Dalam aktualisasinya, regulasi tersebut tidak pernah benar-benar dilaksanakan. Pemerintah Belanda lebih memilih keberpihakan pada agama Kristen, yaitu dengan adanya Sekolah-sekolah Kristen yang dianggap sebagai sekolah pemerintah serta mendapat subsidi rutin dari pemerintah Hindia Belanda. ${ }^{11}$

Terlacak bukti bahwa kebijakan diskriminatif pemerintah Hindia Belanda menjdi pemantik reaksi umat Islam, baik secara defensif maupun progresif. Reaksi defensif tentu dilakuka oleh ulama tradisional, dengan cara menghindari semaksimal mungkin atas pengaruh politik kolonial Belanda terhadap sistem pendidikan Islam. Kemudian reaksi progresif dilakukan dengan adanya pertimbangan bahwa manuver dan dominasi Hindia Belanda dengan pola pendidikan modernis yang cenderung sekuleris harus dilawan dan dipacu dengan pendirian lembaga dan institusi modern berbasis keislaman. Dengan

${ }^{10}$ Misi pemerintah kolonialisme pada saat itu tahun 1882 pemerintah Belanda membentuk suatu badan ksusus yang bertugas mengawasi kehidupan beragama dan pendidika islam yang disebut dengan priesterden. Tahun 1925 pemerintah belanda mengeluarkan Ordonansi guru yang isinya mewajibkan bagi setiap guru agama melaporkan diri pada pemerintah colonial secara berkala dan ordonansi juga mengontrol para guru juga sepak terjangnya dala mengajar terkait spiritualis keislaman yang membehayakan bagi mereka. Ibid, h. 285

11 Muhammad Qosim, Madrasah di Indonesia Pertumbuhan dan perkembangan, Tadris. Volume 2. Nomor 1. 2007

Al-Madrasah: Jurnal Ilmiah Pendidikan Madrasah Ibtidaiyah

Vol. 4, No. 1, Juli-Desember 2019 
begitu, reaktualisasi progresif ini dilakukan umat islam dengan cara "melakukan penolakan, namun juga menirukan".

Melalui konsepsi moderat ini, berdirilah sejumlah madrasah dan sekolah umum yang bercorakkan Islam dengan beberapa otonomi khas: Pertama, Madrasah didirikan dengan alasan untuk melakukan dominasi mata pelajaran agama ditambah mata pelajaran umum, sebagaimana yang dilaksanakan di Madrasah Adabiyah Padang Panjang pada tahun 1909. Kedua, pendirian sekolah bercorak umum model Belanda ditambah mata pelajaran agama agar meningkatkan daya spiritualis agamis, seperti yang dilakukan Sekolah Adabiyah Padang pada tahun 1915. Ketiga, madrasah dengan mata pelajaran sepenuhnya agama adalah madrasah diniyah yang dikelola secara modernis, juga yang dilakukan Madrasah Sumatera Thawalib pada tahun 1919. ${ }^{12}$

Pertumbuhan dan perkembangan selanjutnya, secara bertahap pendirian lembaga-lembaga pendidikan Islam modern dilakukan secara progresif dan masif oleh umat Islam di berbagai regional diseluruh Indonesia dengan berbagai inovasi dan misinya. ${ }^{13}$

\section{Kebijakan madrasah di awal kemerdekaan}

Tepat pada tangal 17 agustus 1945 dimana Indonesia mendeklarasikan kemerdekaannya atas sejumlah penjajahan kolonialisme yang selama ini meradang diatas penderitaan seluruh rakyat Indonesia termasuk para Ulama Tradisional yang telah jauh berjuang untuk melestarikan pendidikan yang bercorakkan islam. Dimana pendidikan saat awal kemerdekaan melakukan upaya pembaharuan dalam bidang pendidikan dan pengajaran, yakni dimana BP KNIP (Badan Pekerja Komite Nasional Indonesia Pusat) dalam

\footnotetext{
12 Ibid, h. 45

${ }^{13}$ Ibid, h. 359
}

Al-Madrasah: Jurnal Ilmiah Pendidikan Madrasah Ibtidaiyah Vol. 4, No. 1, Juli-Desember 2019 
Wahyu Iskandar: Analisis Kebijakan Pendidikan dalam Perspektif Madrasah

sidangnya pada tanggal 29 Desember 1945 membuat sejumlah rekomendasi kepada Kementerian Pendidikan Pengajaran dan Kebudayaan. ${ }^{\mathbf{1 4}}$

Aktualisasi usahanya adalah pembaharuan pendidikan dan pengajaran yang dijalankan sesuai dengan planning rencana pokok $^{15}$ usaha pendidikan dan pengajaran baru yang harus diterapkan diseluruh pelosok negeri. kemudian rekomendasi itu juga disinggung tentang eksistensi madrasah dan pesantren, yakni madrasah dan pesantren yang pada esensinya adalah suatu alat dan sumber pendidikan dalam pencerdasan rakyat biasa yang sudah mengakar dalam paradigma masyarakat kita umumnya, hendaklah demikian mendapat perhatian dan asupan moril juga finansial dari pemerintah dalam upaya membentuk program strategis yang berkualitas bagi madrasah. ${ }^{16}$

\section{Kebijakan Madrasah dibawah Departemen Agama}

Adanya perlawanan ideologis politis dari sebahagian besar elite islam sebagaimana menmbulkan kecurigaan dan rasa tidak suka dari pemerintah terhadap umat islam, namun dengan adanya sebagian elite

${ }^{14}$ BP KNIP dibentuk tanggal 22 Agustus 1945 oleh PPKI (Panitia Persiapan Kemerdekaan Indonesia) dan dilantik tanggal 29 Agustus 1945 di Gedung Kesenian Pasar Baru Jakarta dengan ketua Kasman Singodimedjo. Berdasar maklumat Wakil Presiden Nomor X (16 Oktober 1945) KNIP, sebelum terbentuk MPR dan DPR, diserahi tugas sebagai legislatif. Dalam melaksanakan tugas KNIP dalam kegiatn rutinitas sehari hari, dibentuklah Badan Pekerja KNIP yang para keanggotaannya dipilih dari anggota KNIP yang ada.. Ketua Harian KNIP adalah St. Sjahrir. Baca dalam Ensiklopedi Nasional Indonesia 3 (Jakarta : Delta Pamungkas, 1997), h. 2830.

15 Planning atau perencanaan adalah fungsi pertama dan utama yang harus dilakukan stake holder sebelum mengerjakan komponen yang lain. Perencanaan program tentunya terarah dan jelas untuk pengembangan potensial keseluruhan aspek, baik rencana jangka panjang maupun jangka pendek, dari usaha perencaan tersebut harus ada penjabaran yang dihasilkan, keudian diperoleh dukungan dana untuk sumber daya apa saja yang dibutuhkan. Brent Davis dan Linda Elison menuturkan rencana strategis itu adalah sebuah analisis sistematis dari seklah untuk mencapai visi dari apa yang diinginkan. Lihat didalam Dede Rosyada, Paradigma Pendidikan Demokratis, (Jakarta, Prenada Media Group, 2007), h. 229-230

${ }^{16}$ Ibid, h. 46

Al-Madrasah: Jurnal Ilmiah Pendidikan Madrasah Ibtidaiyah Vol. 4, No. 1, Juli-Desember 2019 
muslim yang berpandangan progresif, modern dan nasionalis melakukan komunikasi yang baik terhadap pemerintah. Maka dengan adanya BP KNIP yang mengusulkan mendirikan Departemen Agama, ${ }^{17}$ dimana pendidikan agama setelah kemerdekaan Indonesia dilakukan secara formal Instutisional. ${ }^{18}$

Upaya pertama Kementerian Agama dalam melakukan pembinaan terhadap keberadaan madrasah adalah memberi asupan dan bantuan berupa pengadaan sarana dan prasarana serta biaya administrasi dan operasional, sebagaimana yang tertulis dalam Peraturan Menteri Agama Nomor 1/1946, tanggal 19 Desember 1946. Dimana regulasi tersebut diterangkan agar madrasah juga mengajarkan pengetahuan umum sedikitnya 1/3 dari jumlah jam pelajaran yang dilaksanakan. Mata pelajaran umum dimaksud meliputi; bahasa Indonesia, membaca dan menulis huruf Latin, berhitung untuk tingkat dasar. Ditambah dengan ilmu bumi, sejarah, kesehatan tumbuh-tumbuhan dan alam untuk tingkat lanjutan. ${ }^{19}$

Tepat pada tahun 1975, tepatnya tanggal 24 Maret 1975, dikeluarkan Surat Keputusan Bersama (SKB) Nomor 6/1975 dan Nomor 037/U/1975 antara Menteri Agama, Menteri Pendidikan dan Kebudayaan, dan Menteri Dalam Negeri tentang Peningkatan Mutu Pendidikan pada Madrasah. Latar belakang lahirnya SKB 3 Menteri bermula dari keluarnya Keputusan Presiden Nomor 34/1972, tanggal 18

17 Pembentukan Kementerian Agama ini diusulkan pertama kali (kepada BP KNIP) pada tanggal 11 Nopember 1946 dan diulang lagi tanggal 25-28 Nopember 1945, oleh KH. Abu Dardiri, KH. Saleh Su'aedy, dan M. Sukoso Wirjosaputro (semuanya anggota KNIP dari Karesidenan Banyumas). Atas dasar usulan tersebut, BP KNIP sepakat membentuk Kementerian Agama. Baca lebih lanjut dalam; Azyumardi Azra, "HM. Rasjidi BA; Pembentukan Kementerian Agama dalam Revolusi", dalam Azyumardi Azra dan Saiful Umam, ed. Menteri-Menteri Agama RI; Biografi Sosial Politik (Jakarta : INIS, 1998), h. 5-6.

${ }^{18}$ Ibid, h. 318

${ }^{19}$ Ibid, h. 48

Al-Madrasah: Jurnal Ilmiah Pendidikan Madrasah Ibtidaiyah Vol. 4, No. 1, Juli-Desember 2019 
April 1972, tentang Tanggungjawab Fungsional Pendidikan dan Latihan, yang sebagian isinya menyatakan bahwa semua lembaga pendidikan di Indonesia berada di bawah tanggungjawab Departemen $\mathrm{P}$ \& $\mathrm{K}$, termasuk lembaga pendidikan agama.21 Umat Islam dan Departemen Agama berupaya agar Kepres tersebut tidak diberlakukan kepada lembaga pendidikan agama, sehingga lembaga ini tetap di bawah naungan Departemen Agama. ${ }^{20}$

Kuatnya penolakan sebagian umat Islam terhadap Kepres tersebut, maka hingga tahun 1974 Kepres Nomor 34/1972 tidak terlaksana secara efektif. Oleh karena itu, Presiden mengeluarkan Instruksi Presiden (Inpres) Nomor 15/1974 yang isinya menginstruksikan agar Kepres Nomor 34/1972 dilaksanakan. Sebagai respon Instruksi Presiden (Inpres) di atas, Menteri Agama berinisiatif menyelenggarakan sidang Majelis Pertimbangan Pendidikan dan Pengajaran Agama (MP3A) yang berlangsung pada tanggal 19-24 Nopember 1974.

\section{Kebijakan Madrasah dalam UU Nomor 20 tahun 2003 dan Data Kemenag dalam Peningkatan Mutu Guru PAI}

Kehadiran UU Sisdiknas Nomor 20/2003 semakin memperkuat posisi madrasah atas penyempurnaan UU no 2 tahun 1989. Di antara indikatornya adalah penyebutan secara eksplisit madrasah yang selalu bersanding dengan penyebutan sekolah, hal ini tidak ditemukan dalam undang-undang sebelumnya. ${ }^{21}$

Beberapa pasal berikut akan menunjukkan hal dimaksud yaitu Pasal 17 ayat 2 : Pendidikan dasar berbentuk Sekolah Dasar (SD) dan Madrasah Ibtidaiyah (MI) atau bentuk lain yang sederajat serta Sekolah

\footnotetext{
${ }^{20}$ Zakiyah Daradjat, "Pengantar", dalam Maksum, Madrasah, h. vii-xiii.

${ }^{21}$ Ibid, h. 57
}

Al-Madrasah: Jurnal Ilmiah Pendidikan Madrasah Ibtidaiyah Vol. 4, No. 1, Juli-Desember 2019 
Menengah Pertama (SMP) dan Madrasah Tsanawiyah (MTs) atau bentuk lain yang sederajat. Pasal 18 ayat 3 : Pendidikan menengah berbentuk Sekolah Menengah Atas (SMA), Madrasah Aliyah (MA), Sekolah Menengah Kejuruan (SMK), Madrasah Aliyah Kejuruan (MAK) atau bentuk lain yang sederajat.

UU No 20 Tahun 2003 yang termasuk kedalam sistem pendidikan Nasional termasuk pesantren, Raudhatul Atfal taman kanak kanak, dengan masuknya kedalam sistem pendidikan Nasional ini, maka selain eksistensi dan fungsi pendidika islam semakin diakui, juga dihilangkan kesan diskriminasi dan dikotomi. Sejalan dengan itu, maka berbagai perundang undangan dan peraturan yang merupakan turunannya, seperti UU no 14 Tahun 2005 tentang guru dan dosen, peraturan pemerintah No 19 tahun 2005 tentang Standar Nasional Pendidikan, peraturan Pemerintah No 74 Tahun 2005 tentang sertifikasi guru dan Dosen, bukan hanya mengatur tentang guru dan dosen yang berada di bawah kementrian Pendidikan Nasional saja, melainkan juga tentang guru, dosen, standar nasional pendidikan juga jumlah guru dan dosen pada tahun $2018 .^{22}$

Eksistensi Madrasah menjadi lebih terstruktur dalam menjalankan perannya sebagai basis pendidikan islam, dengan diperkuat sebuah data yang memperlihatkan perkembangan sentral madrasah dalam meningkatkan mutu pendidikan di Indonesia. Berikut sejumlah keterangan dari kemenag terkait jumlah responsiv siswa dan mahasiswa yang sudah mempercayai madrasah sebagai lembaga yang bermutu dalam meningkatkan integritas pendidikan :

${ }^{22}$ Ibid, h. 352

Al-Madrasah: Jurnal Ilmiah Pendidikan Madrasah Ibtidaiyah Vol. 4, No. 1, Juli-Desember 2019 
Gambar $1^{23}$

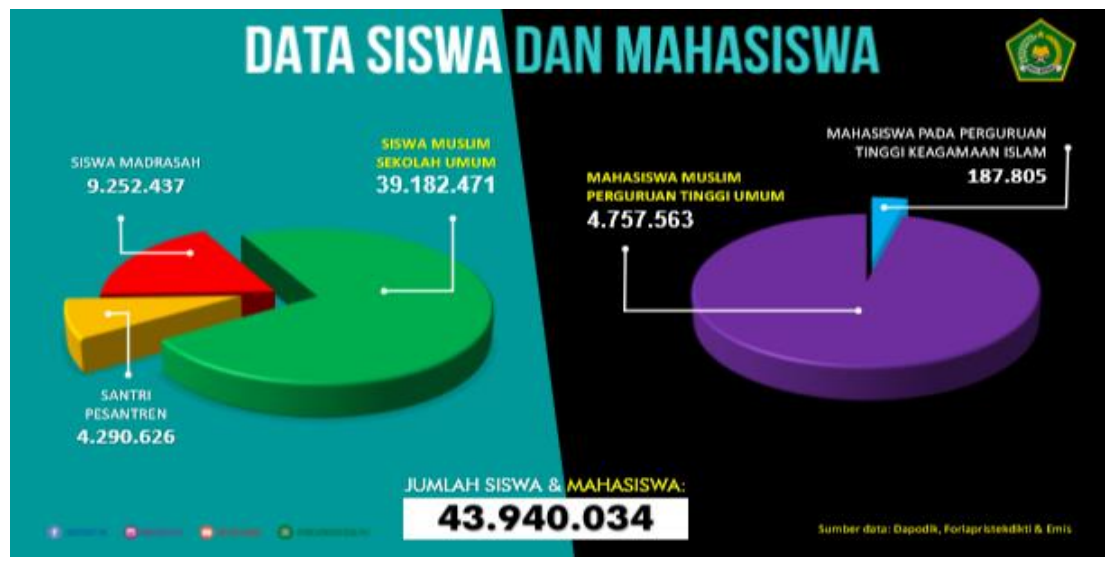

Kemudian ditambah dengan data kemenag terkait jumlah guru PAI dan Dosen:

Gambar $2^{24}$

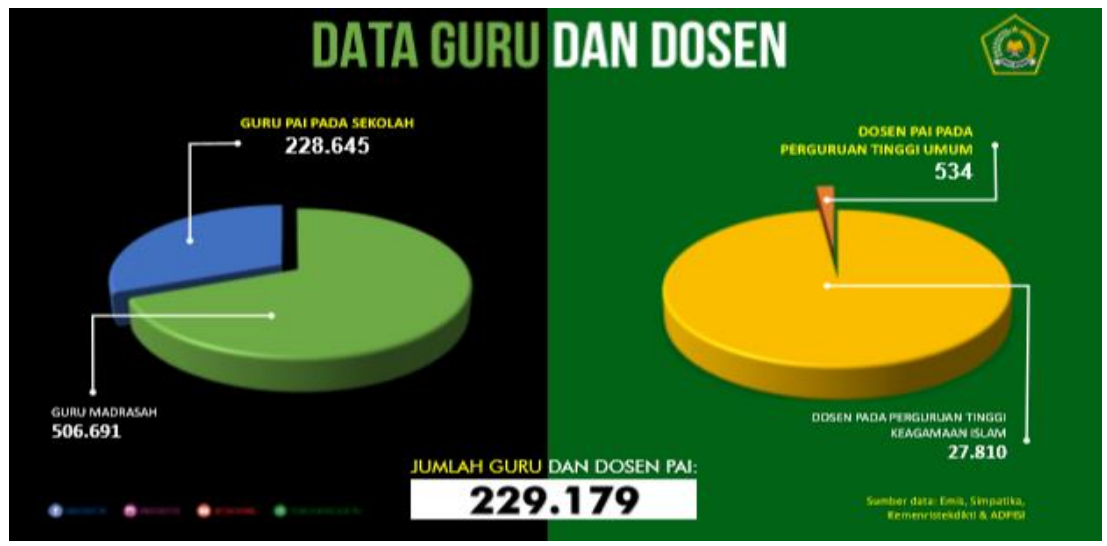

Disamping itu kementrian agama juga membuat kebijakan yang berfungsi untuk meningkatkan mutu pendidikan dengan membuat pelatihan selanjutnya workshop sebagai bagi para pendidik sebagai berikut :

${ }^{23}$ Sumber gambar dari Kemenag RI

${ }^{24}$ Ibid

Al-Madrasah: Jurnal Ilmiah Pendidikan Madrasah Ibtidaiyah Vol. 4, No. 1, Juli-Desember 2019 
Pengelolaan pendidikan madrasah berada dibawah dua kementerian yaitu Kemendiknas dan Kemenag. Pengelolaan ini seringkali menimbulkan kecemburuan terutama dari segi pendanaan, perhatian, bantuan, yang seringkali mendapat perlakuan yang berbeda. ${ }^{27}$ Anggaran pendidikan untuk madrasah yang diambil dari anggaran pendidikan langsung dikelola oleh Kemenag. Namun jumlahnya tidak sebanding dengan jumlah madrasah yang ada di seluruh Indonesia. Sehingga kucuran dana yang diberikan menjadi terbagi dan lebih kecil dibandingkan dengan sekolah umum.

Selain itu kesejahteraan guru di madrasah juga cukup memprihatinkan. Sistem dualisme pengelolaan pendidikan ini memang telah terjadi di Indonesia sejak lama, dan menjadi bentuk jalan kompromi politik kelompok kepentingan dalam masyarakat Indonesia. Hal ini perlu mendapat perhatian khusus. Madrasah secara bersama dengan sekolah umum ikut memajukan pendidikan dan memiliki kontribusi besar terhadap pembangunan dalam menghasilkan lulusan yang tidak hanya cerdas dalam ilmu pengetahuan umum, tetapi juga berbekal ilmu pengetahuan agama. Karena ilmu pengetahuan dan agama juga sangat dibutuhkan manusia, sebab dengan ilmu menjadikan sikap seseorang menjadi kritis. ${ }^{28}$ Dengan demikian Sudah sepatutnya mendapat perhatian ekstra dari dua kementerian ini. Kemenag dan Kemendikbud tentu saja harus mengabaikan ego sektoralnya dalam mengembangkan pendidikan.

pendidikan, buku dan alat perga dan sumber yang lain. Ketiga, peran serta masyarakat khususnya orangtua dalam penyelenggaraan pendidikan kurang dioptimalkan. Pola pembangunan sistem pendidikan nasional telah menjauhkan lembaga pendidikan dari lingkungan masyarakatnya. Lihat dalam Arif Rohman, Memahami pendidikan dan Ilmu pendidikan, (Yogyakarta, Aswaja Pressindo, 2008). h. 262

${ }^{27} \mathrm{Ibid}$, h. 55

${ }^{28}$ Binti Maunah, Landasan Pendidikan, (Yogyakata, Teras, 2009), h. 116

Al-Madrasah: Jurnal Ilmiah Pendidikan Madrasah Ibtidaiyah Vol. 4, No. 1, Juli-Desember 2019 
Menurut Amirullah dalam jurnal aspira vol 5 no 1 :

Hambatan terbesar yang dihadapi madrasah adalah rendahnya kualitas proses pendidikan yang ada didalamnya. Hal ini terjadi karena aspek manajemen, aspek kurikulum dan aspek kualitas tenaga pendidiknya yang dinilai masih rendah. Pada umumnya madrasah masih dihadapkan pada beberapa kendala yang mempengaruhi mutu baik proses maupun hasil pendidikan, baik berkenaan dengan latar belakang siswa dan keluarganya, dukungan berbagai sumber pendidikan, kualifikasi dan rendahnya partisipasi dari masyarakat. Persoalan yang dihadapi madrasah terutama pada pencapaian mutu dipicu karena tidak terpenuhinya standar-standar tertentu, seperti infrastruktur, pendidik dan tenaga kependidikan, kurikulum, calon siswa, proses pembelajaran, dan manajemen kelembagaannya. Pendirian madrasah sering kurang mempertimbangkan pemenuhan aspek mutu baik standar pelayanan pendidikan maupun standar nasional pendidikan. ${ }^{29}$

Melihat permasalan permasalahan diatas dalam berbagai permasalahan madrasah tersebut masih belum diperoleh penyelesaiaannya, meski begitu penyelenggaraan pendidikan madrasah terus berjalan. Kemenag maupun Kemendikbud sebagai aktor penting dalam penyelenggaraan pendidikan di madrasah perlu duduk bersama untuk menyelesaikan permasalahan tersebut sehingga dapat diperoleh titik temu yang selanjutnya dampaknya akan dirasakan oleh seluruh masyarakat Indonesia.

\section{Peluang dan Tantangan Madrasah di Indonesia}

Madrasah merupakan bagian dari Sisdiknas memiliki peran yang cukup penting dalam pendidikan dan sejajar dengan sekolah umum. Perbedaan antara madrasah dan sekolah umum terletak pada sejarah pembentukannya serta ciri khasnya. Dari sisi sejarah, sekolah atau pendidikan umum dibentuk dari model pendidikan umum yang dibangun pada masa kolonialisme Belanda, sementara madrasah dibentuk sebagai respons terhadap pandangan umum bahwa sekolahsekolah Belanda hanya diperuntukkan bagi kaum elit yang berkuasa dan

${ }^{29} \mathrm{Ibid}$, h. 56

Al-Madrasah: Jurnal Ilmiah Pendidikan Madrasah Ibtidaiyah Vol. 4, No. 1, Juli-Desember 2019 
pejabat pemerintahan.

Penyelenggaraan madrasah memiliki peluang dan tantangan tersendiri. Menurut Abdurrahman dalam faridah Alawiyyah :

Peluang madrasah antara lain: pertama, kehidupan beragama yang semakin semarak dan semakin diamalkan dalam kehidupan pribadi maupun dalam sosial kemasyarakatan memberi peluang untuk bersamasama membangun khususnya dalam bidang pendidikan yang mempunyai peranan strategis dalam peningkatan sumber daya manusia. Ditengah krisis moral yang terjadi di Indonesia, pendidikan madrasah menjadi pilihan tepat karena paket pendidikan di dalamnya sudah mencangkup pemberian wawasan ilmu agama. Kedua, semakin berfungsinya Kementerian Agama dalam pembinaan dan pengelolaan madrasah. Hal ini kemudian dikuatkan dengan adanya program strategis Kementerian Agama yakni meningkatkan mutu pendidikan madrasah. Ketiga, adanya animo masyarakat dan gairah beribadah untuk berperan serta dalam ikut serta mencerdaskan kehidupan bangsa dan membangun manusia Indonesia seutuhnya, serta meningkatkan sumber manusia melalui penyelenggaraan madrasah dan memasukkan putra-putrinya pada jenjang pendidikan madrasah. Keempat, adanya peluang untuk mengembangkan program sesuai dengan kemandirian dan ciri kekhususan madrasah sesuai dengan kebutuhan masyarakat dan pembangunan nasional. Kelima, adanya dukungan masyarakat yang sangat luas dalam upaya untuk ikut berperan serta dalam menyelenggarakan madrasah baik dalam hal pengelolaan, pembangunan maupun dalam hal tanggung jawab kemitraan dalam pengabdiannya kepada bangsa, negara dan agama. ${ }^{30}$

Melihat perkembangan ilmu pengetahuan yang begitu cepat, upaya untuk menjadikan madrasah lebih unggul di bandingkan dengan pendidikan umum perlu dilakukan dalam rangka menjawab tantangan tersebut. Kita bisa melihat, bahwa animo masyarakat untuk kembali pada nilai-nilai agama begitu besar sehingga akan lebih mudah melakukan pengembagan ilmu pengetahuan berwawasan agama. Selanjutnya madrasah juga memiliki tantangan sendiri dalam menyelenggarakan pendidikan.

Tantangan penyelenggaraan pendidikan madrasah antara lain: pertama, perkembangan ilmu pengetahuan, teknologi, perubahan sosial

${ }^{30}$ Ibid, h. 57

Al-Madrasah: Jurnal Ilmiah Pendidikan Madrasah Ibtidaiyah Vol. 4, No. 1, Juli-Desember 2019 
dan globalilsasi yang demikian cepat, yang tidak dibarengi percepatan konsepsional, teknik metodologi maupun administrasi, managemen di lingkungan madrasah. ${ }^{31}$ Kedua, hambatan birokrasi dalam penataan prosedur pengembangan baik kelembagaan madrasah, organisasi, administrasi serta kurikulum dan teknik metodologinya. Ketiga, tuntutan komputerisasi dalam sistem administrasi kependidikan, kelengkapan alat-alat laboratorium dan perpustakaan yang masih diperlukan meningkat secara luas dan profesional berkenaan dengan tuntutan yang dihadapinya. Keempat, implementasi kemitraan dan penyelenggaraan pendidikan pada madrasah antara pembina dan masyarakat pengelola madrasah belum dikembangkan secara optimal dan profesional. Kelima, ketidaksiapan pelaksanaan pendidikan di madrasah berkenaan dengan tuntutan kurikulum perkembangan ilmu pengetahuan dan teknologi serta perubahan sosial khususnya dalam hubungan kemampuan teknik metodologi dan manajemen pendidikan. Keenam, perkembangan pendidikan pada madrasah pada umumnya diselenggarakan oleh masyarakat yang latar belakang ekonominya rendah, namun demikian harus menampung siswa yang datang dari kalangan masyarakat yang kurang mampu. Maka akan selalu dihadapkan pada kesulitan pembiayaan operasional pendidikan dan berakibat rendahnya mutu pendidikan yang diselenggarakan. ${ }^{32}$ Ketujuh, ketidaksiapan pelaksanaan pendidikan di madrasah berkenaan Pengetahuan dan teknologi serta perubahan sosial, khususnya dalam hal

31 Dalam pendidikan era modern sebaiknya pemerintah juga memusatkan pandangan modernisasi sebagai tolok ukur utama sebagai manusia (antroposentrisme), memberikan upaya tersendiri dalam merekontruksi era digital agar pendidikan modernisasi merekat di kalangan masyarakat juga pesertadidik. Lihat dalam Fatchul Muin, Pendidikan Karakter kontruksi teoritik dan praktik, (Yogyakarta, Arruz Media, 2016), h. 312

${ }^{32} \mathrm{Ibid}, \mathrm{h} .59$

Al-Madrasah: Jurnal Ilmiah Pendidikan Madrasah Ibtidaiyah Vol. 4, No. 1, Juli-Desember 2019 
kemampuan teknik metodologi dan manajemen pendidikan.

Berbagai peluang dan tantangan tersebut menjadikan madrasah harus berpacu dalam memajukan pendidikan dan tidak boleh kalah dengan pendidikan umum lainnya. Upaya pemerintah untuk memajukan madrasah juga sudah nampak dari adanya salah satu program strategis di Kemenag untuk meningkatkan mutu madrasah yang tertuang dalam Rencana Pembangunan Jangka Menengah Nasional (RPJMN) 20102014 yang menyebutkan bahwa pada bidang pendidikan, kebijakan nasional diarahkan kepada peningkatan akses, kualitas, dan relevansi pendidikan menuju terangkatnya kesejahteraan hidup rakyat, kemandirian, keluhuran budi pekerti, dan kemandirian bangsa yang kuat.

Rencana tersebut direalisasikan dalam sejumlah kebijakan strategis yang mengarah pada upaya perbaikan mutu pendidikan madrasah mulai dari tingkat Raudhatul Athfal sampai pada Aliyah. Pemerintah harus memberikan perhatian lebih melalui penataan, pembinaan, serta pengawasan terhadap pendidikan di madrasah sehingga dapat terus maju dan berkembang bersama dengan sistem pendidikan nasional. Pengembangan program pendidikan seharusnya tidak hanya dilakukan pada pendidikan umum, akan tetapi juga madrasah. Tidak dapat dipungkiri bahwa kemajuan madrasah akan berpengaruh pada kemajuan pendidikan di Indonesia, terlebih dengan semakin meningkatnya jumlah dan mutu madrasah.

\section{Simpulan}

Melihat perkembangan madrasah di Indonesia, ada dua momentum yang sangat menentukan eksistensi madrasah; pertama, SKB 3 Menteri 1975 yang menjadi pintu masuk pengakuan madrasah sebagai lembaga pendidikan Islam yang setara dengan sekolah umum; 
kedua, UU Sisdiknas Nomor 2/1989 yang menjadikan madrasah bukan saja sebagai lembaga pendidikan yang setara dengan sekolah umum, lebih dari itu madrasah diakui sebagai sekolah umum berciri khas agama Islam. Dengan kata lain, sejak UU Sisdiknas Nomor 2/1989 diberlakukan, madrasah dapat dikatakan sebagai "sekolah umum plus". Kemudian permasalahan tata kelola madrasah antara dua mentri masih menjadi PR bagi pemerintah untuk membuat regulasi yang jelas dan transparan bagi pendidikan Indonesia. Juga peluang dan tantangan tersebut menjadikan madrasah harus mampu berpacu dalam memajukan pendidikan dan tidak boleh kalah dengan pendidikan umum lainnya sehingga peran madrasah sangat sentral dimasyarakat. 


\section{Daftar Pustaka}

Azra, Azyumardi. Pendidikan Islam : Tradisi dan Modernisasi di Tengah Tantangan Milenium III. Jakarta: Kencana Prenada Media Group, 2012.

Basrowi, Suwandi. Memahami Penelitian Kualitatif. Jakarta: Rineka Cipta, 2008.

Bungin, Burhan. Metodologi Penelitian Kualitatif. Jakarta: Raja Grafindo Persada, 2011.

Djumransjah, HM dan Abdul Malik Karim Amrullah. Pendidikan Islam. Malang: UIN Malang Press, 2007.

Ibn Al-Asy'ats, Abu Daud Sulaiman. Sunan Abi Dawud. Jilid 4. Cairo: Dar AlHadits, 1988.

Ibn Hanbal, Ahmad Ibn Muhammad. Al-Musnad. jilid. Beirut: Maktabah AlTurats Al-Islamiy, 1994.

Majid, Abdul dan Dian Andayani. Pendidikan Karakter Perspektif Islam. Bandung: Remaja Rosdakarya, 2011.

Masyhud, M. Sulthon, dan Moh. Khusnurdilo. Manajemen Pondok Pesantren. Jakarta: Diva Pustaka, 2005.

Maunah, Binti. Perbandingan Pendidikan Islam. Yogyakarta: Teras, 2011.

Moleong, Lexy J. Metodologi Penelitian Kualitatif. Bandung: Remaja Rosdakarya, 2007.

Mujib, Abdul. Kepribadian Dalam Psikologi Islam. Jakarta: Raja Grafindo Persada, 2006.

Mulyana, Deddy. Metodologi Penelitian Kualitatif: Paradigma Baru Ilmu Komunikasi dan Ilmu Sosial Lainnya. Bandung: Remaja Rosdakarya, 2006.

Nata, Abuddin. Pemikiran Para Tokoh Pendidikan Islam. Jakarta: Raja Grafindo Persada,2003.

Rahmaniyah, Istighfarotur. Pendidikan Etika : Konsep Jiwa dan Etika Perspektif Ibnu Miskawaih Dalam Kontribusinya di Bidang Pendidikan. Malang: UIN Maliki Press,2010.

Ramayulis dan Samsul Nizar. Ensiklopedi Tokoh Pendidikan Islam, Mengenal Tokoh Pendiikan di Dunia Islam dan Indonesia. Ciputat: PT. Ciputat Press Group, 2005. 
Wahyu Iskandar: Analisis Kebijakan Pendidikan dalam Perspektif Madrasah

Setiawan, Agus. Prinsip Pendidikan Karakter dalam Islam (Studi Komparasi Pemikiran al-Ghazali dan Burhanuddin al-Zarnuji), Dinamika Ilmu, 14 (1), 2014

Syahidin. Menelusuri Metode Pendidikan dalam Al-Qur'an. Bandung: CV. Alfabeta, 2009.

Undang-Undang Sistem Pendidikan Nasional No.20 Tahun 2003.

Zuhairini dkk. Filsafat Pendidikan Islam. Jakarta: Bumi Aksara, 2008.

Al-Madrasah: Jurnal Ilmiah Pendidikan Madrasah Ibtidaiyah Vol. 4, No. 1, Juli-Desember 2019 
Wahyu Iskandar: Analisis Kebijakan Pendidikan dalam Perspektif Madrasah

Al-Madrasah: Jurnal Ilmiah Pendidikan Madrasah Ibtidaiyah Vol. 4, No. 1, Juli-Desember 2019 